資料

\title{
化学沈着法による $\mathrm{PbS}$ 光導電セルの試作 ${ }^{\dagger}$
}

\section{1. 緒}

\section{言}

T.S. Moss は PbS 光導電セルの製作は科学ではなく 芸術であるといっている1)が，筆者は以前真空蒸着法に よって比較的感度の良いセルを高歩どをりで（約 $80 \%$ ） 得る方法を発表した2).

$\mathrm{PbS}$ 七ルを作るには真空蒸着による方法のほかに， $\mathrm{PbS}$ 膜を適当な基板上に化学的に沈着生成させ, 適当 な酸化処理を行なうことによって, 光電感度を増大させ てセルに仕上げる方法（化学沈着法）があり，具体的方 法については種々報告されている344)が，こうして作ら れた $\mathrm{PbS}$ セルは感度の点で, 真空蒸着法によって作ら れたものに比べて相当劣る場合が多い4)とされてきた。

しかし化学沈着法は真空ポンプ, 真空計などの装置を 必要とせず，またセルの受光面の形状を自由にすること が，比較的容易であるなどの利点を有するので，筆者は 最近化学沈着法による $\mathrm{PbS}$ セルの試作研究を行なって きたが，酸化処理方法を工夫することによって，蒸着型 七ルに匹敵する感度を有するセルを良い歩どまりで容易 に製作することができるようになったので，以下それに ついて，製作方法汇重点を置いて述べることにする。

\section{2. 製 作 方 法}

化学沈着法による $\mathrm{PbS}$ 七ルの製作過程を, 適当にく ぎりをつけて表現してみると，(1) 基板汇 PbS 膜を沈着 生成させること，(2) 酸化処理，(3) 膜面保護执上び電極 取り付けなどといらことになるので，以下に順を迫って 述べることにする。

\section{$2.1 \mathrm{PbS}$ 膜 の生 成}

$\mathrm{PbS}$ を生成させるのに用いた試薬は, 片山化学秼製で 試薬特級の酶酸鉛 $\left(\mathrm{Pb}\left(\mathrm{CH}_{3} \mathrm{COO}\right)_{2} \cdot 3 \mathrm{H}_{2} \mathrm{O}\right)$ ，千才尿素 $\left(\mathrm{H}_{2} \mathrm{NCSNH}_{2}\right)$ および苛性ソーダ $(\mathrm{NaOH})$ で，まず第 1 表に示すような原料液を作る.

$\mathrm{PbS}$ 膜を沈着生成させる基板には影徽鏡用のスライ ド・グラス，または透明な品ガラスを，顕微鏡用スライ

† Chemically Deposited PbS Photoconductive Cell.

* 山口大学工学部応用物理学教室

Vol. 49 No. 5
正会員山口勝 也*

\begin{tabular}{|c|c|c|c|c|c|}
\hline & & 第 1 表 原 & 料 & 液 & \\
\hline 液 & 名 & 溶 & 質 & 溶 & 媒 \\
\hline \multicolumn{2}{|c|}{ A } & 酢 酸 鉊 & $40 \mathrm{~g}$ & 蒸留水 & $.00 \mathrm{cc}$ \\
\hline \multicolumn{2}{|c|}{ B } & チオ尿索 & $12 \mathrm{~g}$ & 同 & 上 \\
\hline \multicolumn{2}{|c|}{$\mathrm{C}$} & 苛性ソーダ & $65 \mathrm{~g}$ & 同 & 上 \\
\hline
\end{tabular}

ド・グラスの大きさ $(26 \mathrm{~mm} \times 76 \mathrm{~mm}$ ぐらい)に切り 出したものを用い，これに化学的洗浄を施せば最も良い が，水道水 $500 \mathrm{cc}$ に洗剤（ワンダフル $\mathrm{K}$, ブルー・ワ ンダフルなど)，または化粧石けん $5 \mathrm{~g}$ ほどを溶かした ものの中に浸漬して約 15 分 間煮沸したのち, 水道水の 流水中に 30 分間ほど放置したものを用いてもよい.

$\mathrm{PbS}$ 膜を沈着させるには筆者は， $100 \mathrm{cc}$ のビーカー （あらかじめ清浄にして扔く）を反応槽とし，その壁面 に接して流水中から取り出したガラス基板を立て掛ける ようにして並べた．このときなるべくビーカー壁に平行 にビーカー底面に垂直になるように立てる．斜めに立て るとかくはんのじゃまになるし沈着が悪くなる．並べ終 わった状態を上方から見たところを第 1 図に示すが，同 困沉示すごとく顕微鏡用スライド・グラスの寸法で 5 枚

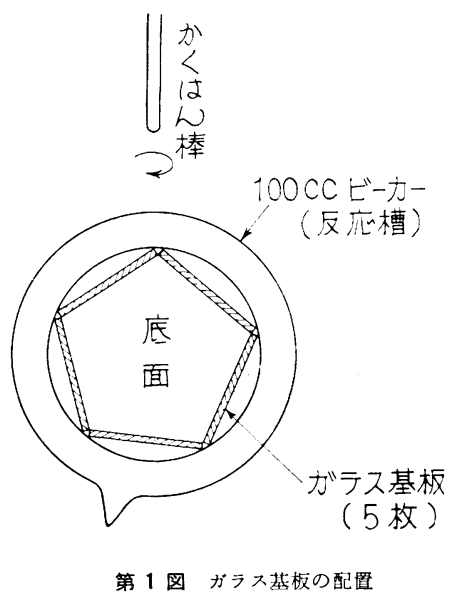

入る.このビーカー汇蒸留水を $30 \mathrm{cc}$ 入れ，次にB液を $25 \mathrm{cc}$ 入れ，そのあとすぐにA液を $25 \mathrm{cc}$ 加えて 2 3 分 間かくはんしてからC液を $20 \mathrm{cc}$ ほど加えてかくはんす る. C液注入々同時にビーカー内の液は強く白濁し, 次 
いでかっ色から黒い鉛色になる.この間約 15〜20 秒ぐ らいで, このあと生成した $\mathrm{PbS}$ が一様にガラス基板上 に沈着するように静かに約 5 分ほどかくはんを続け，そ の後さらに 5 分間ほど放置する. 反応はすべて室温下で 行なわれ，反応槽は加熱も冷却もされていない．

かくはんにはガラス棒を用いた反応槽から，ガラス基 板を取り出してみると, 基板の表裏両面に鏡面状に $\mathrm{PbS}$ 膜が沈着生成されている (銀鏡反応) ${ }^{5}$ ) が, 鏡面状の膜 面に余分の PbS が粒状または泥状に付着しているので, 基板を流水 (水道水) 中に置いて柔らかいら紙で膜面か らこれを取り除く。もしろ紙が無ければ，指先の腹でご く軽く膜面をなでて除去してもよい，次に日陰で乾燥し ガラス切りで希望の大きさに切り出して酸化処理の試料 とする. 筆者は $10 \mathrm{~mm} \times 25 \mathrm{~mm}, 10 \mathrm{~mm} \times 8 \mathrm{~mm}$ のもの を多く製作した。

\section{2 酸 化処 理}

真空蒸着法によって PbS セルを作る場合にもいえる ことであるが，PbS セルの製作に扔いて最も重要であ りまたむずかしい工程は，電子受容体 (エレクトロン・ アクセプター）となる酸素原子を吸着させるため行なわ れる酸化処理である.これを行ならことによって $n$ 型半 導体である $\mathrm{PbS}$ (エレクトロン・ドナーは, 化学量論 的組成より過剩の $\mathrm{Pb}$ 原子) は多量の酸素原子を得るの でドナーである $\mathrm{Pb}$ 原子がコンペンセートされる) て電 気抵抗（暗抵抗）が大きくなり，光照射を受けると価電 子带の電子, 拉よびアクセプターに捕兄られていた電子 が伝導带に励起され，空になったアクセプターにはただ らに価電子帯から電子が励起されるので, 伝導帯にある 電子（自由電子），执よび価電子带にある正孔（自由正 孔）の数は光照射を受けないときよりも多くなり，光導 電現象として観察される.

実際には個々の $\mathrm{PbS}$ 膜に生じている結晶不完全性(電 子トラップ, 正孔トラップ, 再結合センターなど), 特 よびその濃度が種々さまざまであるためと思われるが， $\mathrm{PbS}$ セルの暗抵抗怙よび光電感度は同一原料 $(\mathrm{PbS})$ 同 一方法で作られたものでも相当ばらついた值を示 し2), 製作方法のいかんによっては得られたセルの暗抵抗と光 電感度との関係が，従来の理論78) 飞従わないケースも 報告されているが229)，PbS セル製作の立場から考兄る 々問題は特別な条件が無い限り, いかにして膜の光電感 度が最大になるように, 酸化処理をうまく行ならかとい うことである. 個々のセルについて酸化处理を適切に行 ならことは, 光電感度の測定と酸化処理とを同時に行な うことが困難であるためむずかしい問題である. 特に真 空蒸着法では酸化処理のコントロールが熟練を要するの で，セル製作上の問題点となることが多い。

筆者はこの点を解決するため, 以下に述べる酸化処理
方法を考案した.

$100 \mathrm{~V}, 500 \mathrm{~W}$ の電熱器の上にアスベスト網を置き, 通 電して約 15 分たつとアスベスト面の温度は $320 \sim 340^{\circ} \mathrm{C}$ （室温 $25 \sim 33^{\circ} \mathrm{C}$ ) となり一定するが，そのとき酸化処 理試料をアスベスト上にのせて加熱処理を始め, $\mathrm{PbS}$ 膜 の様子を観察すると，初め鉛色だった膜は約 2 分ほどで かっ色を帯びるようになり, 処理開始後 $4 \sim 5$ 分たつと 濃紺色を带びるようになる. 処理開始後10１5分経過す るとほとんど膜全体が濃紺色を帯びるようになり，さら に加熱を続けると加熱処理開始後約 40 分核に゙で試料の 周縁部の $\mathrm{PbS}$ 膜が白味を帯び始め, 同じく約 1 時間 20 分では相当白味を帯びるようになり，裏面つまりアスべ ストに直接接する膜がはげ落ちるようになる.

このように，加熱処理の進みぐあいによって膜の呈す る色が変化するので, どの段階まで加熱処理を続けた場 合に, 後述する「マッチ処理」の結果も含めて, 最も成 績が良いかを検討したところ，膜全体または大部分が濃 紺色を呈するに至るまで加熱処理をするのが最も良いこ とが知られた．加熱処理の様子を第 2 四に示す.

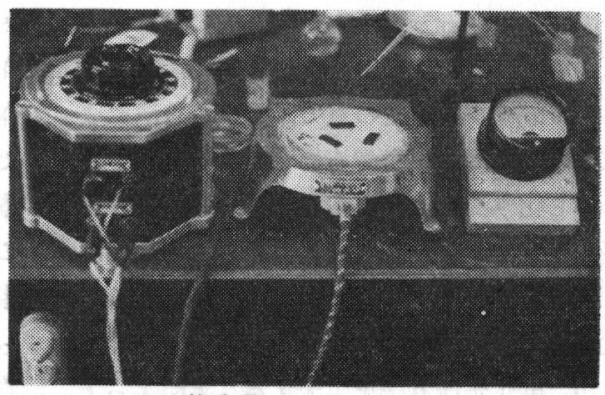

第 2 図加熱 処 理

試料の膜面が艘紺色になったら，試料をアスベスト網 上から耐火レンガ片の上にうつして自然放冷させ，それ から陚料の膜面の受光面になる部分をマッチ（燐寸）の 炎の下の部分で約 $5 \sim 7$ 秒間 (炎が先端部から軸木に移 るまで）焼くのであるが，この場合マッチを発火させて 直後, 先端の薬品部分 (頭薬) が燃焼しているときの炎 を用いる. 軸木が燃えているときの炎では結果は不良で ある.この処理を「マッチ処理」と呼ぶこととしその様 子を第 3 図に示す.

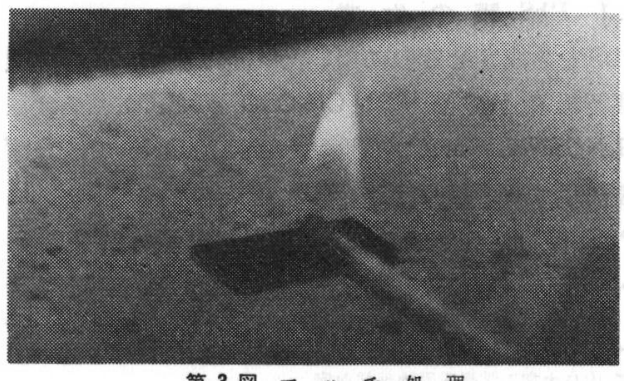

第 3 図 $\checkmark$ チ 処 理 
マッチ処理の前後で試料膜の㛭抵抗を測定すると，マ ッチ处理後は処理前の数倍〜十数倍程度になっているの がわかる.クリップを試料膜の電極取り付け予定場所に 接触させて電気抵抗を測定しながらマッチ処理を行なう と，炎を膜面に接した瞬間から抵抗值が急速に増大する のが見られる.な抮 $\mathrm{PbS}$ 膜は基板の両面に生成されて いるので，マッチ処理は両面に施す。

市販マッチの頭薬には酸化剤として塩素酸カリウムが 含まれ，これは発火すると二酸化マンガンの存在下に $2 \mathrm{KClO}_{3}=2 \mathrm{KCl}+3 \mathrm{O}_{2}$

となって酸素を発生するが, この発生しつつある酸素が 炎による加熱（マッチの下部炎の温度は $1 \mathrm{~mm} \phi$ のアル メル・クロメル熱電対で測定したところ発火後 7 秒ほど で $250 \sim 300^{\circ} \mathrm{C}$ ) によって, PbS 膜に効果的に吸着さ れるものと思われる。

\section{3 膜面保護および電極取り付け}

マッチ処理が終わって自然放冷したら，電極を取り付 ける部分を除いて膜面保護のためにメタアクリル酸樹 脂，またはエポキシル樹脂をうすく塗布する4のである が，筆者は廉価かつ容易に入手し得る市販のビニール用 セスダイン（商品名）を用いて好結果を得た.

第4 図にセメダイン侏製ビニール用セメダインの分光

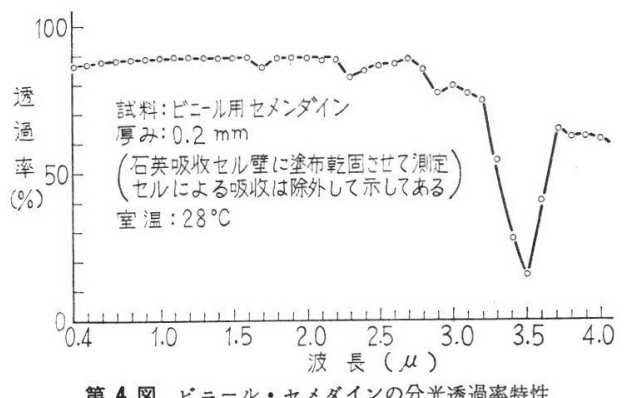

透過率特性を示す. 可視 $3 \mu$ ぐらいまでの波長域にお ける吸収は問題にならないことがわかる。

ビニール用セメダインを両面にうすく塗布して放置し (約 30 分), 固ぬらせたら電極取り付け予定部にクリッ プを接して明抵抗 $(100 \mathrm{~W}$ 電球を受光面から約 $2 \mathrm{~cm}$ 離 して点灯したとき示す抵抗）と暗抵抗とを両面について 測定し (電球テスト)，(暗抵抗)/(明抵抗) の值が 約 10 程度以上のものに電極を付けてセルに仕上げる.

1 個の試料については, 電球テストの成績の良いほう を選ぶ. 電極にはビニール・コードのより線の 1 本を $5 \mathrm{~cm}$ ぐらいに切ったものを用い, 取り付け予定部の膜面 をアルコール扰よびェーテル各 $50 \%$ （v/v) 混液で清拭 し, シルパー・ペースト (米国 Du Pont 社製室温乾燥 型 No. 4817 西進商事秤取扱い)をマッチの軸木の先に つけて盛るように塗り, 電極をペーストに埋めるように

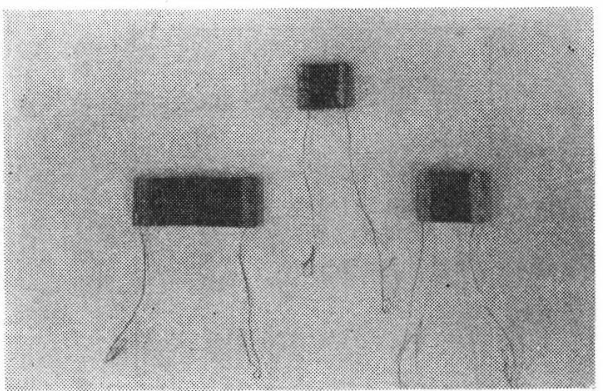

第 5 図完定したセル

塗り込み, そのま乾固（約半日〜一日）させる.でき 上がった $\mathrm{PbS}$ セルを第5 図に示す.な特セルの製作を 急がない場合には次述べるようにすると良い。

すなわちマッチ処理後自然放冷したら, 膜面にビニー ル・セメダインを塗布せず電極を取り付け，約 1 時間ぐ らいたってシルバー・ペーストが半かわきになったらデ シケーター中に入れ，午のま約 $5 \sim 7$ 日間放置する.

こうすると膜の暗抵抗が初めの約 $1 / 3$ 程度になるが， これは $\mathrm{PbS}$ 膜に吸着した酸素が一部離れるためである う. 7 日ぐらいたってデシケーターから取り出したら， 直ちにビニール・セメダインを塗布するが，塗布後膜の 暗抵抗は增大して初めの值に注涪等しい程度となり, 電 球テストの成績はマッチ処理後のそれの 5 10 割程度良 くなる.これはデシケーターに放置して乾燥処理したる のに特有な結果である.

以上述べた方法で $\mathrm{PbS}$ セルを製作した場合の歩どま りは相当良く, 昭和 39 年 8 月 29 日までに 76 個製作しそ のうち電球テストの成績が 10 以上であったものは 65 個 であった．これは筆者が 1 人で製作したのではなく，卒 業研究の学生が製作したものを含んでいる.

\section{4 保存}

完成した PbS セルは湿気と高温を避けて保存する。 デシヶーターに収めて冷暗所值くのが良い。湿気が $\mathrm{PbS}$ 膜の光電感度に良くない影響を与えることはすでに 知られている ${ }^{10}$ 。 七儿を実際に光检知器として使用する 際も, 除湿には十分に留意すべきである。

\section{3. $\mathrm{PbS}$ 膜の諸性質}

次に筆者の方法で製作した化学沈着による $\mathrm{PbS}$ 膜の 電気抵抗, 膜厚扣よび膜構造の X線回折データなどにつ いて述べることにする，な挆電気抵抗と抵抗率は室温の 値である.

\section{1 膜の電気抵抗}

筆者の方法によって, 平滑ガラス基板上に沈着生成直 後の $\mathrm{PbS}$ 膜の電気抵抗は $12 \sim 30 \mathrm{k} \Omega / \mathrm{cm}^{2}$ 程度であり, 統計的には $20 \sim 25 \mathrm{k} \Omega / \mathrm{cm}^{2}$ の值を示するのが約 $60 \%$ 程 度を占めた. 生成直後この程度の値を示す $\mathrm{PbS}$ 膜の電 


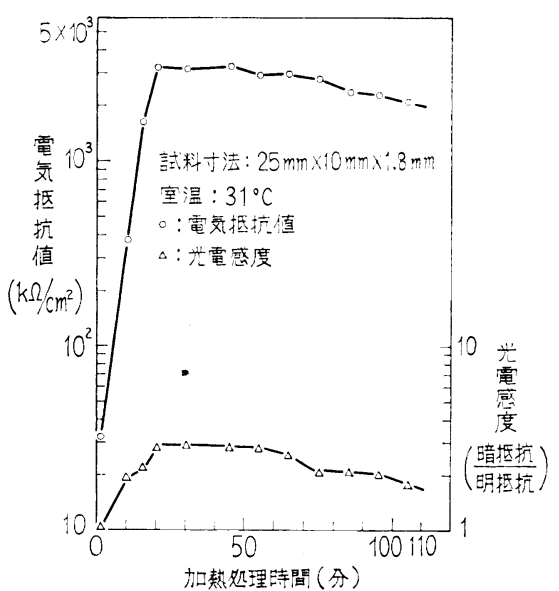

第 6 图西父抵抗值括よび態度の加繁処理時 間汇よる変包

気抵抗が加熱処理を受けることによって，ぞう変化する かの測定例を, 抵抗值測定時の光電感度（電球テストに よる）とともに第 6 図に示す.

抵抗值测定時には試料を放冷し, 試料温度が室温と等 しくなるのを待って測定した. 加熱処理開始後15〜20分 ほどで光電感度が最も良く, 暗抵抗も最も高くなるが, このころほとんど膜全体が濃紺色を呈するようになるわ けである．電熱器による酸化処理が終わった膜にマッチ 処理を行ならと，膜の抵抗值はさらに増加して数〜十数 $\mathrm{M} \Omega / \mathrm{cm}^{2}$ となり光電感度も上畀する. 七ルの製作過程に おける光電感度の電球テスト成績は第 2 表に示すようで せる.

第 2 表光䉓感度の店化

\begin{tabular}{c|c|c|c}
\hline & 沈着生成直後 & $\begin{array}{c}\text { 加熱 処 理 後 } \\
\left(320^{\circ} \mathrm{C}, 15 \text { 分间 }\right)\end{array}$ & マッチ処理後 \\
\hline \begin{tabular}{c|c} 
暗抵抗值 \\
明抵抗值
\end{tabular} & $1.01 \sim 1.05$ & $3 \sim 5$ & $10 \sim 30$ \\
\hline
\end{tabular}

また 0 ～ $60^{\circ} \mathrm{C} て ゙$ 完成したセルの暗抵抗值（Rd）の温 度特性を, $\log \mathrm{Rd}$ 対 103/T でプロットし，その直線の こう配から $\sigma=\sigma_{0} \exp \left(-E_{G} / 2 R T\right)$ の関係を用いて活性 化エネルギー $E_{G}$ の值を求めたところ, $0.3 \sim 0.35 \mathrm{eV}$ の 值を示すものが多かったが，これは筆者が以前発表した 蒸着法による高抵抗型セルの場合 ${ }^{2}$ に似ている.

\section{2 膜原}

酸化処理しない人工 $\mathrm{PbS}$ の電気抵抗率 $\rho$ は約 $1 \Omega \cdot \mathrm{cm}$ である11) から, 今沈着生成直後の $\mathrm{PbS}$ 膜の電気抵抗を $R \Omega$ ，長さを $a \mathrm{~cm}$ ，幅を $b \mathrm{~cm}$ ，膜厚を $d \mathrm{~cm}$ とすれば

$$
R=\rho \cdot \frac{a}{b \cdot d}
$$

と書けるから，この式から膜厚 $d$ は $d=\rho \cdot a / R \cdot b$ として 計算することができる. 第 3 表に数個の $\mathrm{PbS}$ 膜の $1 \mathrm{~cm}^{2}$ 当たりの電気抵抗值 $\left(R_{s q}\right)$ 拈よび膜厚の值を示す. 膜
第 3 表 膜 厚

\begin{tabular}{c|c|c}
\hline 七 & $R_{s q}(\mathrm{k} \Omega)$ & $d(\mu)$ \\
\hline A & 28.8 & 0.36 \\
B & 12.5 & 0.82 \\
C & 43.7 & 0.24 \\
D & 25.1 & 0.40 \\
E & 22.5 & 0.46 \\
\hline
\end{tabular}

厚は $0.4 \sim 0.8 \mu$ ぼどである.

\section{3 膜 の X 線回折}

理学電機製 X 線回折装置ガイガーフレックスを用いて 得た $\mathrm{PbS}$ 膜の X 線回折データについて述べる. $\mathrm{X}$ 線回 折の実験条件は $\mathrm{Cu}$ ターゲット使用, 加速電压 $30 \mathrm{kVP}$, 同電流 $13 \mathrm{~mA}$ ，スケール・ファクタ 16 , タイム・コン スタント 2 秒, マルチプライヤー1, スキャン・スピー ド每分 $2^{\circ}$ ，スリット $0.4 \mathrm{~mm}$ であり，この条件は終始 不変である.

第 7 図（a）にガラス基板に沈着生成直後の $\mathrm{PbS}$ 膜の $\mathrm{X}$ 線回折データを示し, 同図 (b) に $320^{\circ} \mathrm{C}$ で 15 分間 加熱処理した後のデータを，同図（c）に 15 分間 $320^{\circ} \mathrm{C}$

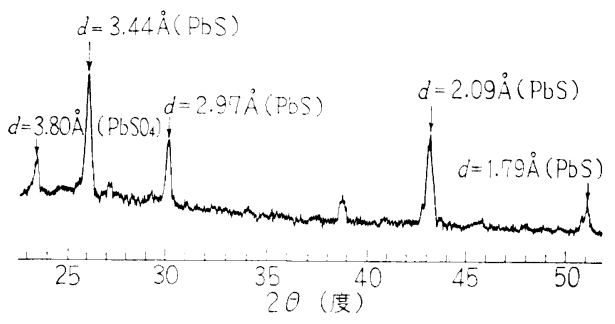

第 7 図（a） 沈着生成直後の X 線回析データ

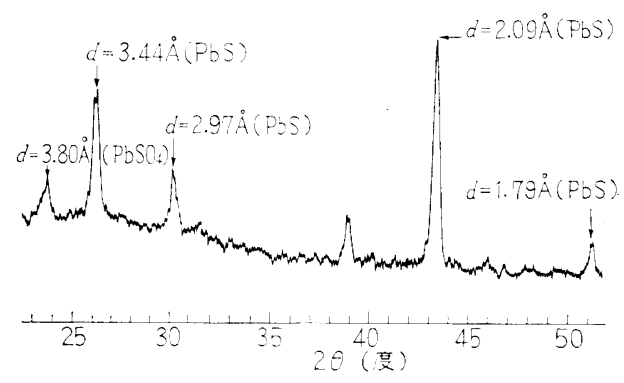

第 7 図 (b) $320^{\circ} \mathrm{C} 15$ 分間加熱処理後のX 線回析データ

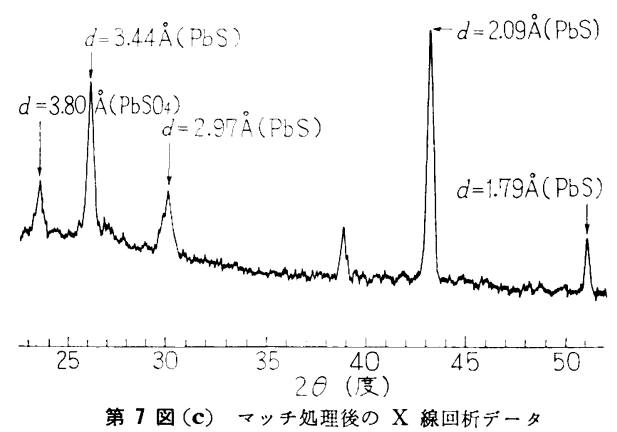


で加熱処理後, さらにマッチ処理を行なったもののデー タを示す.

$\mathrm{X}$ 線回折実験は同一試料膜について，生成直後 $\rightarrow$ 加熱 処理後 $\rightarrow$ マッ処理後と一貫して行ない $\mathrm{PbS}$ 膜の結晶 状態が加熱処理，マッチ処理によってどら変化するかを 明らかにした，第 7 図から加熱処理によって， $\mathrm{PbS}$ 膜の 結晶状態は著しく良くなり，さらにマッチ処理後回折線 の強度はさらに強くなり, 結晶状態がさらに良くなって いることが知られる. わずか数秒間の処理であるがマッ チ処理は, 結晶状態を改善することがX線回折データか ら明りょらに示された。

\section{4. 光 電 諸 特 性}

\section{1 感度}

$100 \mathrm{~V}, 100 \mathrm{~W}$ の電球をセルの受光面から $2 \mathrm{~cm}$ の距離 で点灯したときのセルの抵抗を明抵抗 $(\mathrm{Rb})$ とし，暗抵抗 (Rd) との比 $\mathrm{Rd} / \mathrm{Rb}$ から，以前筆者が発表した方法 ${ }^{2}$ で感度(これを NEI，NEP などに対して直流感度と呼 ぶことにする）Sを测定した結果の数例を，筆者が以前 試作した蒸着型セルのそれと此較して第 4 表に示す. 直 流感度の点では蒸着型セルに見劣り無いことがわかる.

第 4 表 感 度

\begin{tabular}{c|c|c|c}
\hline セル名 & $\mathrm{Rd}(\mathrm{M} \Omega)$ & $\mathrm{Rd} / \mathrm{Rb}$ & $\mathrm{S}$ \\
\hline No. 16 & 7.0 & 10 & 1.0 \\
No. 27 & 16.0 & 20 & 1.30 \\
No. 35 & 12.0 & 21 & 1.32 \\
No. 36 & 9.0 & 23 & 1.36 \\
No. 74 & 1.3 & 16 & 1.20 \\
蒸着 $\$ 24$ & 1.0 & 31 & 1.50 \\
蒸着 77 & 1.4 & 15 & 1.18 \\
\hline
\end{tabular}

\section{2 電压電流特性}

セルに印加する直流バイアス電压を変化させたときの 䀧電流（Id），拈よび光電流（ $\Delta I=$ 放射エネルギー入射

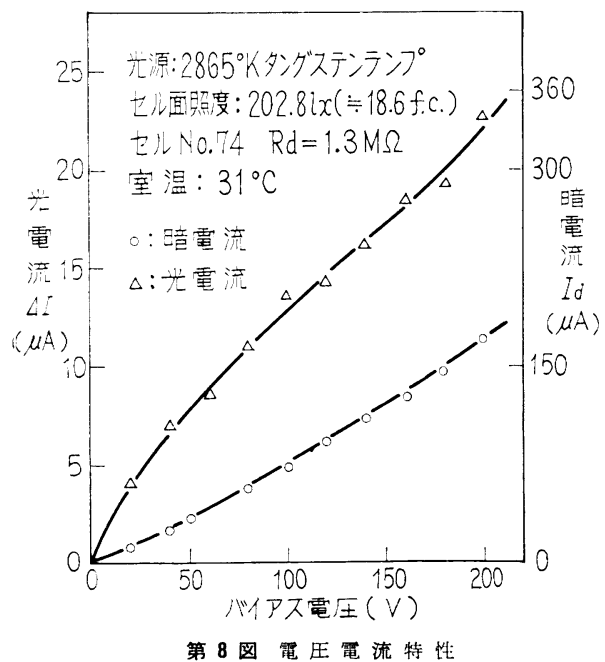

時の電流—-Id）の変化の様子を第 8 図に示す. バイア ス電压に対する直線性はほぼ良好であり，光電流も相当 大きく蒸着型のそれ(2) に比してほとんど少らないこと が知られる。

\section{3 照度光電流特性}

光源ランプとセルとの距離を変えて, セル受光面の照 度を変化させたときの直流光電流の変化の様子を，第 9

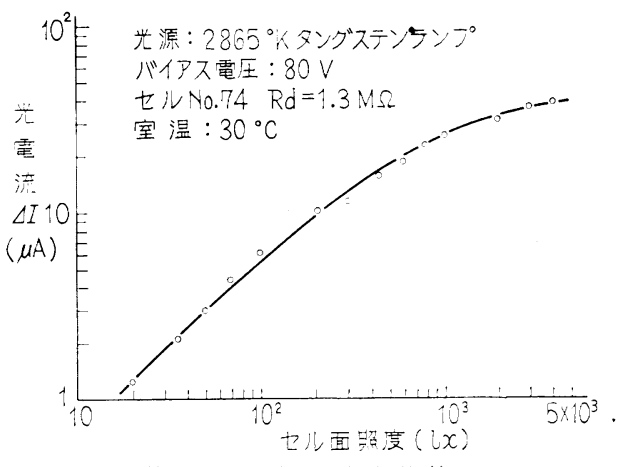

第 9 図照度光管流特性

図に示さ．照度が大体 $1,0001 \mathrm{x}$ 以下では光電流は照度 に比例し，1,000 lx 以上では飽和の傾向を示す.

\section{4 時 定 数}

光源ランプからの光を，チョッパーによって断続光と して PbS セルの受光面上に投射し, 出力信号を並列 T 型乃波器を通して選択増幅し, 真空管電生計で読み取っ た. $\mathrm{PbS}$ セルから信号を取り出すには PbS セル，バイ アス用電池扣よび $\mathrm{PbS}$ セルの $\mathrm{Rd}$ と等しい抵抗值をも つ負荷抵抗 $\left(R_{L}\right)$ を，閉回路を形成するように直列に接 続し， $R_{L}$ の両端から増幅器入力端子へ信号を加えた.

一般に光照射により増加した電気伝葲度が，最大値の $1 / e$ に減衰するに装する時間を光導電体の時定数 $\tau^{13)}$ と 寸れば，入力光信号の周波数が $f \mathrm{c} / \mathrm{s}$ のをき, 負荷抵抗 の雨端に生起する信号出力電压 $V_{f}$ は $V_{0} を f=0$, また はそれに近い低周波（4 $\pi^{2} f^{2} \tau^{2} \ll 1$ なるような周波数） における信号出力電压とすれば,

$$
V_{f}=V_{0} /\left(1+4 \pi^{2} f^{2} \tau^{2}\right)^{1 / 2}
$$

の関係がある，供試セルについて，周波数特性を测定し て得られた結果，すなわち $V_{f} / V_{0}$ の值からてを計算し た結果, $50 \sim 130 \mu S$ の間の值を取るものが多かった $\mathrm{PbS}$ セルの時定数は $20 \sim 100 \mu S$ といわれているが14), 短い 時定数のものはあまり見られなかった。

\section{5 分光感度特性}

水晶分光器を用いて得られた $\mathrm{PbS}$ セルの分光感度特 性を測定した代表的测定例を第 10 図に示す多くのセル が $1.2 \mu$ 付近で最大感度を示したが，これは以前筆者が 発表した蒸着法により製作した高抵抗型セルのそれによ く似ている。

Vol. 49 No. 5 


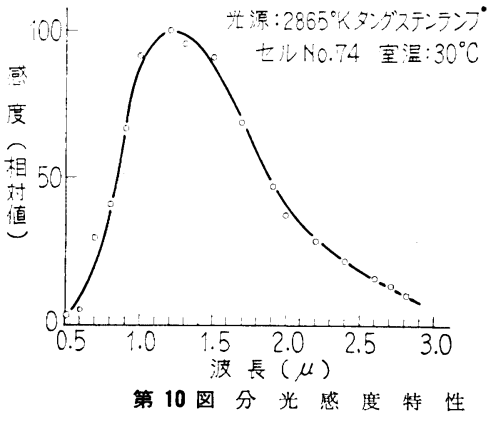

\section{6 信号雑音特性}

放射エネルギー源として， $T^{\circ} K$ の黑体炉（放射発散 率 $\varepsilon \doteqdot 1)$ を用いた場合, 炉の面積を $A\left(\mathrm{~cm}^{2}\right)$, 炉面から $\mathrm{PbS}$ セルの受光面までの距離を $D(\mathrm{~cm}) ， \sigma$ を StefanBoltzmann の定数とすれば，七ル面の放射照度 $E$ は

$$
E=\frac{\sigma \cdot T^{4}}{\pi \cdot D^{2}} A\left(W / \mathrm{cm}^{2}\right)
$$

で表わされる15)放射源の温度を $500^{\circ} \mathrm{C}$ とし，セルの受 光面に入射する一定の放射エネルギーをチョッパーで断 続したとき，七ルの負荷抵抗の両端に生ずる信号電压， 雑音電生扣よび网者の比 $(S / N$ 比) が，七ルに供給され るバイアス電圧によりどう変化するかの 测定例を第 11 図に示す $S / N$ 比を最大にするバイアス電压が，この場 合の最適バイアス電压となる.

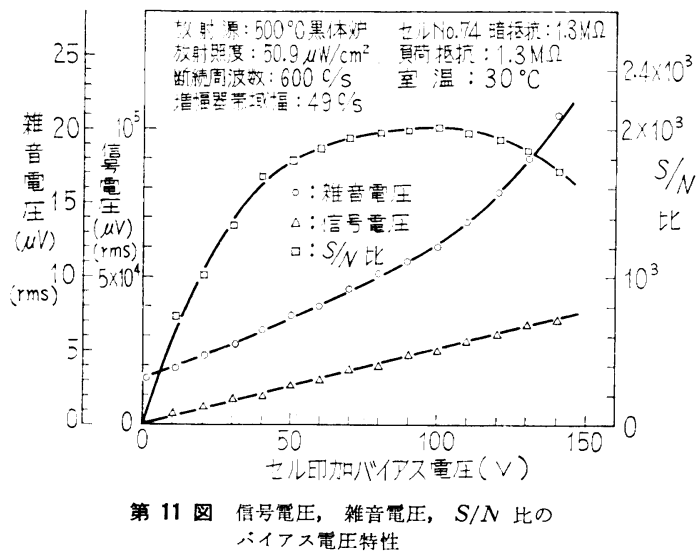

\subsection{NEI および NEP}

(3)式により計算されたセル面放射照度，および実測に より得られたセルの $S / N$ 比の值から, 供試セルの NEI

（雑音等価入力）および NEP（雑音等価パワー）を次 式14）従って計算した.

$$
\begin{aligned}
& \mathrm{NEI}=\frac{E}{S / N \cdot(\Delta f)^{1 / 2}} \cdot \frac{\sqrt{2}}{\pi}\left(W / \mathrm{cm}^{2}\right) \\
& \mathrm{NEP}=\frac{E \cdot A}{S / N \cdot(\Delta f)^{1 / 2}} \cdot \frac{\sqrt{2}}{\pi}(W) \ldots
\end{aligned}
$$

$\Delta f$ は用いた増幅器の带域幅で, この場合チョッピン
グ周波数は $600 \mathrm{c} / \mathrm{s}, \Delta f=49 \mathrm{c} / \mathrm{s}$ で放射源温度は $500^{\circ} \mathrm{C}$, セル面放射照度は $50.9 \mu W / \mathrm{cm}^{2}$ である。

第 5 表に数個の代表的セルについて NEI および NEP の值を求めた結果を示す. 蒸着により得られた $\mathrm{PbS} セ$

第 5 表 NEI, NEP (室温: $30^{\circ} \mathrm{C}$ )

\begin{tabular}{l|c|l|l|l}
\hline 七ル名感光面積 & $\begin{array}{c}\text { NEI } \\
\left(\mathrm{cm}^{2}\right)\end{array}$ & $\begin{array}{c}\text { NEP } \\
\left(W / \mathrm{cm}^{2}\right)\end{array}$ & 備 & 考 \\
\hline No. 27 & 0.4 & $1.12 \times 10^{-9}$ & $4.48 \times 10^{-10}$ & \\
No. 35 & 0.5 & $9.87 \times 10^{-10}$ & $4.94 \times 10^{-10}$ & \\
No. 36 & 0.5 & $5.62 \times 10^{-10}$ & $2.81 \times 10^{-10}$ & \\
No. 74 & 0.5 & $1.63 \times 10^{-9}$ & $8.15 \times 10^{-10}$ & \\
H-40814) & 0.25 & $9.23 \times 10^{-10}$ & $2.26 \times 10^{-10}$ & 蒸着, $3^{\circ} \mathrm{C}$ \\
$\# 7116)$ & 0.28 & $2.17 \times 10^{-9}$ & $6.21 \times 10^{-10}$ & 蒸着, $25^{\circ} \mathrm{C}$ \\
\hline
\end{tabular}

ルのそれと比較してみると，今回の実験が室温下で行な われた（セル冷却はしていない）ことを考えれば，決し て蒸着により作られたセルのそれに比して見劣りあるも のでは無いことがわかる。

\section{8 経 時 変 化}

製作後セルの暗抵抗および感度が，どのように経時変 化するかを测定した例を第 12 図扣よび第 13 図に示す. 製作後数日たつと, 暗抵抗执よび感度は一定となり, 以 後ずっと安定である。

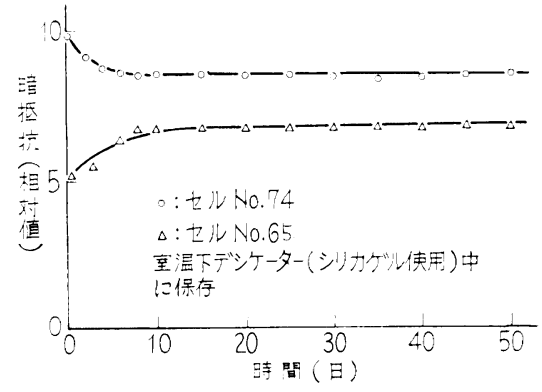

第 12 図暗抵抗の程時资化

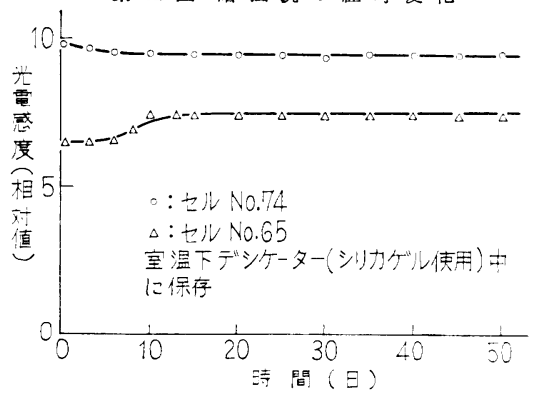

第 13 图光電感度の経時变化

\section{5. 討論とまとめ}

従来化学沈着法によりつくられた $\mathrm{PbS}$ 光導電セルの 感度 (直流感度) は, 蒸着法によりつくられた $\mathrm{PbS} セ$ ルのそれの約 $1 / 10$ 程度4)であるとされてきたが，筆者 は PbS 膜の酸化処理方法を工夫し，

(1) $\mathrm{PbS}$ 膜の色変化によって加熱処理を制御し， 
（2）マッチ処理を行ない，

(3) 乾燥処理を行なう

ことによって, 従来の方法で得られなかった感度の良い セルを高歩どまりで得ることができるようになった. 得 られたセルについて光電諸特性を测定した結果, 蒸着法 により作られたセルの諸特性と比較して, 見少り無いこ とが明らかにされた。

筆者の方法によれば, 蒸着法に拉けるごとく高価な排 気装置や蒸着, および酸化処理のめんどらな技術および 熟練は不要である. 試薬, シルバー・ペースト, ビーカ 一, 電熱器, アスベスト網, ガラス片, マッチ, ビニー ル・セメダイン, デシケーター, それに薬品を秤量する 簡単なはかからがあれば製作可能であり，むずかしいテク ニックは無く入手困難な物も無い。特に高感度な $\mathrm{PbS}$ セルを要求するのでなければ，この方法によってきわめ て安価かつ容易に PbS セルを得ることができるわけで ある. 化学沈着法によれば, 七ル受光面の面積および形 状を任意にすることが比較的容易なので，今後この利点 を生かした光電装䀇の開発を行ないたいと思っている.

終わりにのぞみ本研究を遂行するにあたり，実験を熱 心に手伝ってくれた電気工学科卒業研究学生山田紘二郎 君に厚く感謝する.

\section{文献}

(1) T.S. Moss : Proc. IRE, 43 (1955) 1869

(2) 山口勝也：応用物理，30 (1961) 172
(3) F. Kicinski : Chem. in Ind., 17 (1948) 54

(4) 盛田・河野：防大和文紀要, 1 (1963) 65

(5) 化学大辞典第 2 卷, 共立出版 (東京) (1960) 906

(6) Richard H. Bube : Photoconductivity of Solids, John Wiley \& Sons Inc. (New York ((1960) 175

(7) J.C. Slater: Phys. Rev. 103 (1956) 1631

(8) P.W. Kruse, L.D. McGlauchlin and P.B. McQuistan : Elements of Infrared Technology, John Wiley \& Sons Inc. (New York) (1961) 400

（9）小川・工藤：応用物理, 32 (1963) 81

(10) Ковьасюк В.П., Чорна Н.С. : Украин Физ. Жур. 8 (1963) 1150

(11) T.S. Moss : Optical Properties of Semiconductors, Butterworths Scientific Publications (London) (1959) 181

(12) 三橋・今村：テレビジョン, 13 (1950) 181

(13) M.Smollett, J.A. Jenkins : Electronic Engineering, 9 (1956) 372

(14) 小黒正光：東芝レビュー，15（1960）994

(15) A.S. Locke : Guidance, D. Van Nostrand Company Inc. (New York) (1955) 129

(16) 山口勝也：応用物理, 31 (1962) 240

（1964年10月22日受付） 